\title{
Kernos
}

Revue internationale et pluridisciplinaire de religion grecque antique

$21 \mid 2008$

Varia

\section{Personal protection and tailor-made deities: the use of individual epithets}

Jenny Wallensten

\section{(2) OpenEdition \\ Journals}

Electronic version

URL: https://journals.openedition.org/kernos/1602

DOI: 10.4000/kernos. 1602

ISSN: 2034-7871

\section{Publisher}

Centre international d'étude de la religion grecque antique

Printed version

Date of publication: 1 January 2008

Number of pages: 81-95

ISSN: 0776-3824

\section{Electronic reference}

Jenny Wallensten, "Personal protection and tailor-made deities: the use of individual epithets", Kernos

[Online], 21 | 2008, Online since 01 October 2011, connection on 24 August 2022. URL: http:// journals.openedition.org/kernos/1602 ; DOI: https://doi.org/10.4000/kernos.1602 


\title{
Personal protection and tailor-made deities: the use of individual epithets
}

\begin{abstract}
The use of epithets was a fundamental component of Greek polytheism. The present study brings attention to a small subgroup of such divine bynames, referred to as individual epithets because they stem from the names of mortal individuals. The function of these epithets is to designate a deity specifically concerned with the individual in question, thereby providing a close relationship and personal benefits for the eponymous worshipper and his or her close kin. The article exemplifies the phenomenon through the investigation of a goddess Isis Aphrodite Dikaia identified in Hellenistic Delos. Through the epithet Dikaia, two Athenian brothers, Dikaios and Asklepiades, sons of Dikaios, intimately tie the deity to themselves and their family. It is moreover proposed that a positioning of the epithet in its historical and physical context furthers our understanding of its origins and significance.

Résumé : L’usage des épithètes était une composante fondamentale du polythéisme grec. Cet article se penche sur un petit groupe de surnoms de ce genre, que l'on appelle des épithètes individuelles, dans la mesure où elles dérivent du nom d'individus mortels. Ces épithètes ont pour fonction de montrer qu'une divinité est particulièrement concernée par l'individu en question, fournissant dès lors une relation étroite et des bienfaits personnels pour le fidèle éponyme et sa famille proche. L'étude illustre le phénomène en investigant la déesse Isis Aphrodite Dikaia que l'on rencontre dans la Délos hellénistique. Par l'épithète Dikaia, deux frères athéniens, Dikaios et Asklépiadès, fils de Dikaios, associent intimement la divinité à eux-mêmes et à leur famille. Il est en outre proposé qu'un replacement de l'épithète dans son contexte historique et physique approfondit notre compréhension de ses origines et de sa signification.
\end{abstract}

\section{The use of epithets in Greek cult}

The gods and goddesses of the Greeks could be called by an infinite amount of epithets that presented their various functions and honours. The epithet of the deity attached a certain function to a certain god, and thereby its use in ritual established a link between the worshipper and the god relating to the named function. Therefore, in attempts at communication with the divine, epithets were used as precision tools: a suitable epithet would ensure that a prayer or promise reached just the right aspect of the intended recipient. ${ }^{1}$

* I wish to thank the Kernos referees for their valuable comments that helped improve my text. I am also very grateful to Prof. E. Rystedt, Dr. H. Gerding and Dr. M. Mili for helpful discussions on an earlier version of the paper. 
There is agreement among scholars that the use of epithets is a vital component of Greek polytheism and that, in spite of this, it is a surprisingly little studied phenomenon. Thus, many fundamental questions are still contested issues. There is for example no agreement among scholars as to which component of an epithet-clad god took precedence during interaction with the gods through prayer and sacrifice. When invoked through a double name, was it the choice of god, say Hermes, or the epithet, say, Agoraios, which mattered the most? Opinions cover the whole spectrum: Brule argues that in theory, a god without an epithet is but "un artefact du langage" and not a true recipient of cult, whereas Pirenne-Delforge, without denying the importance of epithets, stresses the priority of the divine names, i.e., over-arching divine identities. ${ }^{2}$ The related question of whether a god, through the use of a byname, in fact becomes a "new" and separate divinity, or whether on the contrary a collection of all epithets given to a certain god rather creates his or her unified identity, is likewise a vexed one. ${ }^{3}$ Discussions end unsolved, but often with the consolation that the ancient Greeks themselves apparently did not have a problem with a myriad of apollos co-existing with the great god Apollo. 4

As Parker points out, as a further step towards an understanding of the role of epithets in Greek cult practice, it is clear that we must try to go beyond the temptation of mere collection and classification of epithets. Epithets, like the divinities themselves and their functions, have an historical and physical context, they do not "float in the air" and their place in time and space might in many cases be the key to our understanding of what are otherwise just empty titles. ${ }^{5}$ The present study tries to take these factors into consideration and presents a certain epithet, Dikaia, in context. The paper argues that the epithet belongs to a small group of divine bynames stemming from the names of mortal individuals and I therefore refer to them as individual epithets. The function of these epithets is to designate a deity specifically concerned with the individual in question, thereby providing a close relationship and personal protection for the worshipper and his or her close kin. Through the epithet Dikaia, two Athenian brothers, Dikaios and Asklepiades, sons of Dikaios,

1 See for example R. PARKER, "The problem of the Greek cult epithet”, OAth 28, (2003), p. 173-183; P. BRULÉ, "Le langage des épiclèses dans le polythéisme hellénique", Kernos 11, (1998), p. 13-34; W. BURKERT, Greek Religion, Oxford 1985, p. 184.

2 Brulé, l.c. (n. 1), p. 18-19; V. Pirenne-Delforge, L'Aphrodite grecque, Liège, 1994; V. Pirenne-Delforge, "La notion de " panthéon » chez Pausanias", in V. Pirenne-Delforge (ed.) Les panthéons des cités. Des origines à la Périégèse de Pausanias, Liège, 1998 (Kernos, suppl. 8), p. 129-148 (the latter study takes Pausanias' treatment of deities/epithets as point of reference).

3 See for example PARKER, l.c. (n. 1), p. 175, with references to a classic study of Vernant (J.P. Vernant, Mythe et pensée chez les Grecs, Paris, 1971, p. 87, n. 23) discussing the fact that Xenophon could have the favour of Zeus Basileus while simultaneously have fallen out of favour with Zeus Meilichios.

${ }^{4}$ See for example PARKER, l.c. (n. 1), p. 181-182.

${ }^{5}$ PARKer, l.c. (n. 1), p. 174, 176, 182. 
intimately tie the goddess Isis Aphrodite Dikaia to themselves and their family. It is moreover proposed that a positioning of the epithet in its historical and physical context furthers our understanding of its origins and significance.

\section{Dedications to Isis Aphrodite Dikaia}

\section{IDélos 2158}

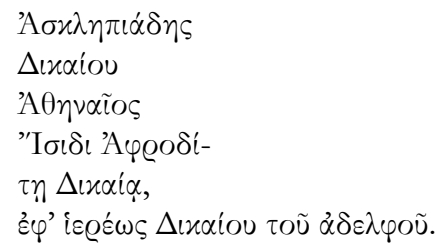

The goddess Isis Aphrodite Dikaia has been identified in one, or possibly two, inscriptions. The only absolutely certain appearance of the deity is found in the intact dedication IDélos 2158. The inscription was carved on a marble base, found in the excavations of Sarapieion C, the public sanctuary of the god in Delos, in 1911.

The message of IDélos 2158 is succinct: Asklepiades, son of Dikaios, the Athenian, dedicated to Isis Aphrodite Dikaia, when his brother Dikaios was priest. ${ }^{6}$ It is noteworthy that the dedicator Asklepiades chose to include a dating formula in his short inscription, expressed through the priesthood of his brother. ${ }^{7}$ In this kind of private dedications, dating formulas are not mandatory. The dedicator surely decided the wording deliberately; through the inclusion of the priesthood dating, variants of the name Dikaios reoccur conspicuously in the inscription: Dikaiou-Dikaia-Dikaiou.

A second possible occurrence of Isis Aphrodite Dikaia can be found in what has been identified as a dedication from Asklepiades brother, Dikaios himself (IDélos 2040). ${ }^{8}$ This inscription is however quite damaged and its

${ }^{6}$ LGPN 2, Asklepiades 113; Dikaios I, LGPN 2 9, father of Dikaios II, LGPN 2, 10.

7 The inscription does not specify which priesthood Dikaios held. It is not likely that it was in fact that of Isis Aphrodite Dikaia. Probably he was priest of Sarapis at the time of the erection of the votive. The find context corroborates this, as the fact that we know from other Delian inscriptions that Dikaios held a priesthood of this god in 94/93 BC or 92/91. See also IDélos 2039. The Isieion of Delos was located in the vicinity of Sarapieion C (F. DuNAND, Le culte d'Isis dans le bassin oriental de la Méditerranée II, Leiden, 1973, p. 90).

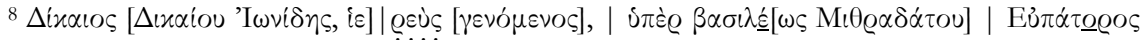

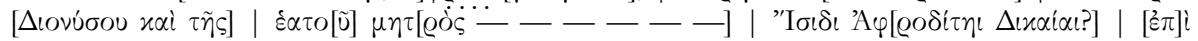

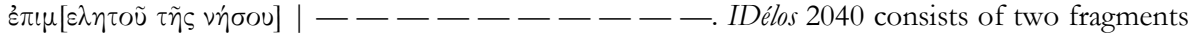
(inv. A 3004 and E 666) found in Sarapieion C in 1911. Fragment A (lines 1-2) is the upper left corner of a marble base. Fragment B (lines 3-7) is a marble plaque, once clamped to another object. See P. Roussel, Les cultes égyptiens à Délos du III e au Ier siècle av. J.-C., Paris/Nancy, 19151916, p. 170-171, no. 161. - Mithradates Eupator is honoured in several Delian inscriptions, see for example IDélos 1560, 1561 and 2039, the latter an inscription put up by 'our' Dikaios of IDélos 
restoration must depend on IDélos 2158. If the restoration is correct, it can be noted that Dikaios' offering also is of a private character. He did not present it in the capacity of priest, but after his term in office. ${ }^{9}$

\section{Individual epithets}

In a testamentary dedication from early Hellenistic Kos, a certain Diomedon creates a cult for the benefit of his family. ${ }^{10}$ Diomedon addresses his attention to a Herakles who holds the epithet Diomedonteios, thus, a Herakles invoked through a byname stemming from the given name of the dedicator Diomedon himself. Sherwin-White believes that the epithet becomes the means of "a merging, if not identifying" of Diomedon's personality with that of Herakles. ${ }^{11}$ The designation Diomedonteios is however simultaneously an example of another phenomenon: a sub-group of bynames that I propose to call individual epithets'. Divine epithets in this complex can be adjectives or expressed through a genitive: what unites them is that they are derived from the names of mortals. They are thus individual in the sense of being created from the personal name of an individual as well as in the sense of themselves designating an individual god, known only from one very specific context and connected to specific individuals for personal benefits. Rather than expressing a merging of Herakles and Diomedon, I believe that the epithet Diomedonteios proudly calls attention to a personal relationship between the god and his worshipper, and indicates that Diomedon enjoys Herakles' special favour and protection. Diomedonteios designates a narrow and sharply defined aspect of Herakles, concerned exclusively with Diomedon and his offspring. ${ }^{12}$ Another example of

2040. For the relations of Mithradates, Delos and Athens, see for example F. DürrbACH, Choix d'inscriptions de Délos vol. I, Paris, 1921, p. 188-189.

${ }^{9}$ This would give a terminus post quem for the dedication, 94/93 or 92/91 BC. For a discussion on the temporal meaning of genomenos, with further references, see C. HASENOHR, "Les collèges de magistri et la communauté italienne de Délos" in Les italiens dans le monde grec IIe siècle av. J.-C. Ier siècle ap. J.-C., Paris, 2002 (BCH, Suppl. 41), p. 72, n. 29. Cf. G. SCHÖRNER, Votive im römischen Griechenland. Untersuchungen zur späthellenistichen und kaiserzeitlichen Kunst- und Religionsgeschichte, Stuttgart, 2003 (Altertumswissenschaftliches Kolloquium, 7), p. 144, who believes that this wording implies that a dedication was put up as an official took on his duties. This is not the generally accepted interpretation, and it is not clear what evidence corroborates this standpoint.

${ }^{10}$ LSCG 177=ICos ED 149. The stele presents three documents, carved by three different hands at various points in time. The first and earliest part of the inscription, A 1-B 55, includes the dedication to Herakles Diomedonteios. It has been dated (on account of the letterforms) to a period c. 325-300 BC. Herzog dated the remaining sections to c. 300 BC (1, B 56-68) and c. 280, or the early third century (2, B 69-D), respectively (R. Herzog, Heilige Gesetze von Kos, Berlin, 1928, p. 29).

11 S. SHERWIN-White, Ancient Cos. An historical study from the Dorian settlement to the Imperial period, Göttingen 1978 (Hypomnemata. Untersuchunben zur Antike und zu ibrem Nacbleben, 51), p. 364.

12 SHERwiN-White, o.c. (n. 11), p. 364. Only the offspring of Diogenes could hold the priesthood of Herakles Diomedonteios (ICos ED 149 A, 9ff; D 136ff. See also SHERwIN-WhiTe, o.c. (n. 11), p. 365, w. n. 631). 
an individual epithet is to be found in the literary sources. Plutarch mentions in the Moralia that an Aphrodite Dexikreontos was invoked in Samos. The passage also suggests possible circumstances for the creation of such epithets: the name was given to the goddess as a token of gratitude after a proof of the goddess' goodwill. Following the advice of Aphrodite, the merchant Dexikreon set out on a commercially successful voyage and in the aftermath he thankfully dedicated a statue of this goddess. ${ }^{13}$

As far as we can tell today, as in the case of Herakles Diomedonteios, Isis Aphrodite Dikaia was another deity that existed only in the context of a certain family, that of Dikaios through his sons Dikaios and Asklepiades. Surely the coherence of divine and mortal names is not a coincidence. Pierre Roussel comments briefly on the matter: "De plus il n'est point surprenant que des membres d'une famille où était porté le nom $\Delta i x \alpha \iota$ os aient vénéré Isis Dikaia". ${ }^{14}$ I believe that we can qualify this statement and develop it further. I suggest that the Isis Aphrodite Dikaia of the two Delian inscriptions is a personal protectress of the same exclusive kind as Herakles Diomedonteios and Aphrodite Dexikreontos, created through an individual epithet as an expression of (and a claim to) a special link between god and mortal. ${ }^{15}$ As far as we can tell from the present state of the evidence, this goddess was not honoured elsewhere. Whereas the fusion or assimilation of Isis and Aphrodite can possibly be found in one other inscription from Delos (the restoration is considered doubtful), and has been identified in other parts of the Greek world, ${ }^{16}$ the particular

13 Plutarch, Quaestiones Graecae, 54 (Mor., 303c-d). I owe this important reference to the Kernos referees. Plutarch actually gives sugggestions for the creation of the epithet, both are however connected to the power of Aphrodite: through her goodwill Dexikreon succeeded in a professional mission.

14 Roussel, o.c. (n. 8), p. 171 , no. 162.

15 Perhaps Isis Aphrodite Dikaia was the recipient of recurring worship, just as in the case of Herakles Diomedonteios, or perhaps only honoured by the preserved dedications, erected in the context of a specific family matter. This must remain unclear due to the present state of the evidence. For private cult foundations, see for example A. PURvis, Singular dedications. Founders and innovators of private cults in Classical Greece, New York, 2003.

16 IDélos 2080. The editor considers the restoration of the name of Aphrodite as doubtful. Isis Aphrodite is also known from Amathous in Cyprus (SEG 38, 1501), Perinthos and perhaps from Egypt (Abu el-Matamir, A. BERnAND, Le Delta Égyptien d'après les texts grecs I, 4, Cairo, 1970, p. 925-926). A Delian Isis Soteria Astarte Aphrodite Euploia Epekoos is also attested, IDélos 2132: however, in this case it is unclear whether we are dealing with one or several goddesses. The geographical spread of Isis Aphrodite perhaps suggests that the combination was an established deity or an aspect of either Isis or Aphrodite (or both, depending on the circumstances). If the cross-cultural goddess Isis Soteira Astarte Aphrodite Euploia Epekoos is taken as a single deity, she surely had a strong aspect of a protectress of voyages, as specified by Isis Soteira and Aphrodite Euploia. Are these perhaps the connotations we should perceive by the other dedications to Isis Aphrodite (see below)? A temple of Aphrodite and Isis that seems to have existed in Dendyra should also be mentioned: A. BERNAND, Les Portes du désert. Recueil des inscriptions grecs d'Antinooupolis, Tentyris, Koptos, Apollonopolis Parva et Apollonopolis Magna, Paris, 1984, no. 27. A Delian 
combination Isis Aphrodite Dikaia is not otherwise attested. Nor does the epithet Dikaia occur in combination with either Isis or Aphrodite separately, and rarely, if at all, with other divinities.

The extant Dikaia examples furthermore date to a much later period. In an inscription dated to the second or third century AD, there is mention of the goddess Dikaia Nemesis. ${ }^{17}$ The epithet might also be identifiable in the goddess Artemis Digaia Blaganitis. Hatzopoulos argues that this epithet, spelt in various ways (Deigea, Deigaia, Digaia) is Dikaia in the Macedonian dialect. The published inscriptions mentioning the deity can be dated to AD 189.18 In two further dedications from the late Imperial period, an unknown goddess (or goddesses?) called Hosia and Dikaia, and Meter Makaria Hosia Dikaia are attested, but they all seem clearly unrelated to the Delian Dikaia inscriptions. ${ }^{19}$

More relevant for the understanding of Isis Aphrodite Dikaia is the presence of an Isis called Dikaiosyne in the epigraphic sources of Delos. ${ }^{20}$ IDélos 2079 has an unknown find context, but IDélos 2103 was found in Sarapieion C and has been dated c. 114/113 BC. It thus originates from the same sanctuary and roughly the same chronological context as the Dikaia inscriptions. ${ }^{21}$ The contemporary existence of Isis Dikaiosyne surely had bearings on the nature of Isis Aphrodite Dikaia (see below).

Dikaia is the exact grammatical equivalent neither of Diomedonteios, (i.e. Dikaieia), nor of Dexikreontos (i.e. Dikaiou). It however clearly belongs to the same group of bynames: a complex created by epithets expressing close connections between dedicator and recipient deity which are articulated through a play on the worshipper's given name. Although not strictly translatable as "of Dikaios" or "Dikaian", in the case of IDélos 2158, an intimate link between dedicator and recipient deity cannot be denied. Dikaia, the female

dedication to Isis Mother of the Gods Astarte, IDélos 2101, should also be mentioned in these circumstances.

${ }^{17}$ IG X.2 1, 62 .

18 M. Hatzopoulos, “Artémis Digaia Blaganitis en Macédoine”, BCH 111 (1987), p. 402412; SEG 27, 277.

19 TAM V, 247; MAMA X, 158. See also IG IV, 563, IEphesos 203, w. add. p. 6, for male gods called Dikaios. It is of course notoriously hard to distinguish between formal epithets and 'normal' adjectives in many cases, and maybe to distinguish them would be to create an artificial taxonomy. For an epithet in adjectival form that may have originated as an independent deity, see the case of Artemis or Hekate Enodia (R. PARKER 2005, "Artémis Ilithye et autres : le problème du nom divin utilisé comme épiclèse", in N. BeLAyche et al. (eds.), Nommer les dieux, Rennes,

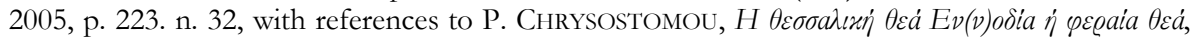
Athens, 1998, p. 187-288.

${ }^{20} I_{G} \mathrm{II}^{2}$, 4702; IDélos 2079, 2103.

${ }^{21}$ For other possible connections Isis-Dikaiosyne, see P. Roussel, o.c. (n. 8), p. 147; DunAND, o.c. (n. 7), 112, Y. GRANDJEAN, Une nowvelle arétalogie d'Isis à Maronée, Leiden, 1975, p. 79-80 w. nn. 184/186. Isis is furthermore paired with several other goddesses in inscriptions found in the Sarapieion C. See for example IDélos 2059 (Nike Isis) and IDélos 2060 (Isis Hygieia). 
variant of the name Dikaios, surely had an individual relationship to Dikaios and Asklepiades Dikaiou. It can even be argued that the possibility of a double entendre of the adjective Dikaia is preferable to the plain Dikaieia or Dikaiou. Not only is the goddess favouring Dikaios, but Justly so. ${ }^{22}$

The possibility that Dikaios himself (and his father Dikaios) was named after the goddess, and not the other way around, must of course be considered. The rarity of the epithet in comparison with the frequency of the name however makes this unlikely. ${ }^{23}$

\section{The context of the inscriptions}

Brule pointedly puts his finger to the sad fact that the importance of positioning epithets and their origins in time and space goes hand in hand with a the frequent impossibility to do just that, due to the fragmentary state of the sources. ${ }^{24}$ In the case of our dedications to Isis Aphrodite Dikaia, we are however fortunate enough to have the Delian find context of the votives as well as dates relating to the careers of the dedicators Dikaios and Asklepiades. If one accepts that the brothers, or perhaps their father, were the first to honour the goddess Isis Aphrodite Dikaia, one is presented with a relatively clear historical and geographical context for the first appearance of the goddess: Delos, in the last half of the second century BC, or in the beginnings of the first. I believe that the larger historical context corroborates these cultic origins. $^{25}$

22 The name Dikaia almost designates the goddess as a family member, the sister of Dikaios and his brother.

23 I thank Dr. N. Papazarkadas for bringing the matter to my attention. 11 men named Dikaios are found in LGPN I, 25 in vol. II, 15 in vol. IIIa and no less than 46 in vol. IIIb, and 13 in vol. IV. The female name Dikaia can be found in vol. I (Dikaie, once), in vol. II (once), vol. IIIa (eight times), and vol IIIb (12 times). We can compare the case of Dikaios and Dikaia with a dedication made by an Isidotos to Isis, SEG 30, 1777 (dated to the end of the 3rd-beg. 2nd century BC), or by a Dionysodoros to Dionysos, SEG 37, 1020. The curious pairing of the Egyptian triad Sarapios, Isis and Anoubis with Aphrodite in IDélos 2098 could perhaps also be explained by the fact that the dedicator's wife is named Aphrodisia? Cf. A. HAuvetTeBesnault, "Fouilles de Délos. Temple des Dieux Étrangers (1)", BCH 6 (1882), p. 473. Neither is the explanation that the dedications are due to Dikaios' family's particular devotion to the goddess Dike a likely one (M.-F. BASLEZ, Recherches sur les conditions de pénétration et de diffusion des religions orientales à Délos (IIe-Ier s. avant notre ère), Paris, 1977 (Collection de l'École normale supérieure de jeunes filles, 9), p. 60). The dedications are simply not presented to this goddess. On theophoric names, see R. PARKER, "Theophoric names and the history of Greek religion", in S. Hornblower \& E. MATTHEWs (eds.) Greek personal names: Their value as evidence, Oxford 2000, p. $53-79$.

${ }^{24}$ BRULÉ, l.c. (n.1), p. 27.

25 A possible previous existence of the goddess does not invalidate the contextual interpretation possible through the extant dedications. The date and setting of our dedications allow us to find at least one layer of the cult of the goddess, valid for the period of worship we can detect in the dedications. 
The appearance of Isis Aphrodite Dikaia specifically in the island of Delos during the time of Athenian dominance is not surprising. Most obviously, the pairing (or identification) of the Egyptian Isis and the Greek Aphrodite mirrors the international melting pot atmosphere of the island. But the deity also testifies to the religious "freedom" of Athenians outside their home city. Many cults were too closely attached to their local context to be exported by an Athenian sent to Delos. These circumstances brought the result that travellers and émigrés could make, and to a certain extant had to make, personal choices regarding which deities to approach in a given situation. ${ }^{26}$ The Delian milieu and Dikaios' and Asklepiades' outsider position, if not absolute prerequisites for the invention of a personal deity, ${ }^{27}$ surely offered more fruitful ground for such actions than the comparatively conservative religious climate of Athens.

But why go to such lengths as to present a deity with a new name? Why not settle for the already forceful combination of Isis and Aphrodite, or perhaps use one of the countless epithet combinations already in circulation? I believe an important part of the answer is to be found in the Hellenistic religious setting.

\section{Hellenistic religious preoccupations}

The propaganda of Alexander and the successor kings frequently made use of divine ancestry and protection. Possibly this, or a slightly earlier context, is where we should start searching for the first appearances of individual epithets of gods in the Greek world. An inscription found in Eresos, Lesbos, makes mention of altars of Zeus Philippios. ${ }^{28}$ Several interpretations of this epithet have been put forth. Habicht understands this god as presenting Philip as a manifestation of Zeus. ${ }^{29}$ This is questionable, mainly because it goes beyond what the words actually state. As Badian points out, Zeus Philippios is literally Zeus of Philip, not Philip who is Zeus. ${ }^{30}$ But other factors also work against it. The chronology of the cult makes it problematic to understand Philip as a bypostase of Zeus. Badian suggests that the cult of Zeus Philippios was instituted after the "liberation" of Eresos and Heisserer has likewise proposed the date

26 J. Mikalson, "Greek Religion. Continuity and change in the Hellenistic period" in The Cambridge companion to the Hellenistic world, G. BOUGH (ed.), Cambridge 2006, p. 209, 211, 217 ; J. Mikalson, Religion in Hellenistic Athens, Berkeley, Los Angeles \& London 1998, p. 208.

27 Compare an example given by PARKER, l.c. (n. 1), p. 175, a "nounce coinage" of the deity Zeus Epiteleios Philios.

${ }^{28}$ IG XII 2, 526. The inscription has been dated to the Hellenistic period, but refers to preexisting altars, see below n. 31.

${ }^{29}$ Ch. HABICHT, Gottmenschentum und griechische Städte, München, 1970 (Zetemata, 14), p. 14-15.

30 E. BADIAN, "The deification of Alexander the Great" in H.J. DELL (ed.), Ancient Macedonian studies in honor of Charles F. Edson (Institute for Balkan studies, 158), Thessaloniki, 1981, p. 27-71, p. 41. 
$336 \mathrm{BC}$ for the erection of the altars. ${ }^{31}$ This would mean that the altars were installed during the lifetime of Philip, something that in turn makes it very unlikely that they would come from a context of a veritable cult of the king. In spite of possible personal divine aspirations, the reception of exceptional perhaps even divine - honours along with the semi-divine status of the Macedonian king, as far as we know Philip was not the recipient of proper cult even at the height of his power.

Sokolowski suggestion that Zeus Philippios corresponds to deities like Zeus Heraios, Zeus Damatrios and Zeus Aphrodisios, and that the epithet indicates a shared cult is another claim that cannot be sustained. In this reasoning, Sokolowski puts inscriptions combining the name of a god and the name of a mortal on a par with those combining the name of a god with that of another deity, and proposes that such epithets indicate "a partnership in a common cult or temple". 32 This understanding of the epithet Philippios (just as Habicht's interpretation) fails to take account of the fact that it is just that, an epithet. Although interpretations vary in detail, with the exception of Sokolowski, scholars agree that the god present in such an epithet does not equal the actual recipient of cult. For example, Sissa and Detienne believe that epithets founded on the name of another god or goddess, such as Aphrodisios, or Areios, are due to the practice of sacrifice to one god on the altar of another. ${ }^{33}$ A related interpretation of these cult titles involves connections between gods in a festival context: in Athens, for example, Zeus Olympios was possibly addressed as Zeus Heraios on the day of the yearly celebration of the Hieros Gamos. ${ }^{34}$ These interpretations cannot be sustained as regards Zeus Philippios. Surely, at this point in history, Zeus was not an occasional visitor at the altar or a festival of Philip. ${ }^{35}$

31 A.J. Heisserer, Alexander and the Greeks. The epigraphic evidence, Norman, 1980, p. 68; E. BADIAN, "Alexander the Great between two thrones and heaven: Variations on an old theme" in A. SMALL (ed.), Subject and ruler: The cult of the ruling power in classical antiquity (JRA suppl., 17), Ann Arbor, 1996, p. 11.

${ }^{32}$ F. SOKOLOwSKI, "Divine honors for Antiochos and Laodike at Teos and Iasos", GRBS 13 (1972), p. 174, n. 11.

33 "Sacrifice to one god on the altar of another could indicate their respective places in a hierarchy, possibly a hierarchy observed in one particular place, or on one particular day. [...] Zeus was very used to sacrifices made to him on the altars of others, so much so that on such occasions he would be called the Zeus of Hera (Zeus Heraios) or the Zeus of Demeter (Zeus Damatrios)" (G. Sissa \& M. DetiEnNe, Daily life of the Greek, gods, Stanford, 2000, p. 162).

34 PARKer, l.c. (n. 1), 180; PARKer, l.c. (n. 19), 221.

35 We can furthermore see that with the possible and much later exception of Zeus Areios (attested in the Imperial period), the gods with "divine epithets" always combine one male and one female god. When two gods are combined, it seems that the pairing consists not of a god with an epithet, but of two juxtaposed names of deities, e.g., Zeus Ares, Aphrodite Hera (PARKER, l.c. (n. 19), p. 219-220, 225). Such a team of gods does not necessarily identify or assimilate the two deities. As Parker points out, these expressions do not deny the distinction between them, but acknowledge the difference (PARKER, l.c. (n. 19), p. 225). - Another approach 
Rather, what the literal reading "Zeus of Philip", or "Philippian Zeus", fundamentally shows, is that for some reason the successful Macedonian king had a claim to a special relationship to this particular deity. Nilsson and Badian understand this relationship as that of a bodyguard, as it were. The altars belong to a cult of the King of the Gods as the Macedonian king's personal protector. ${ }^{36}$ Later evidence identifies a similar deity, Zeus Seleukeios. Two dedications dated to the Imperial period mention this god Nock, however, is of the opinion that this god originated as a protector of the Seleucids. ${ }^{37}$ Of the circumstances of the first uses of these two epithets, we unfortunately know nothing. Perhaps we should imagine a context of gratitude for a specific favour the god showed these rulers, as in the case of Aphrodite Dexikreontos? Or were they coined as a result of the continuous benevolence shown by Zeus that kept the kings on their thrones? In whichever case, I believe that it is the idea of special favours and protection, inherent in both scenarios, that lies behind the further development of divinities tailor-made through the use of individual epithets, those of kings as well as those of more ordinary people like Dikaios. The early epithets Philippios and Seleukeios may to some extent be the result of blurred lines between the divine and the mortal spheres, in a world where it became increasingly accepted to celebrate certain humans with divine honours. But the idea that is picked up and disseminated outside court circles, and finally visible in the appearance of a goddess like Isis Aphrodite Dikaia, is the possibility of a claim for personal protection and relations with the gods, the quest for which permeates religious dealings between deities and men during the Hellenistic period. $^{38}$

connects "divine" epithets with specific functions. As regards Zeus Aphrodisios, see also PIRENNEDELFORGE, o.c. (n. 2). She argues that the epithet indicates not altar-sharing but the sharing of similar functions. In this case, Zeus thus takes on the civic competence of Aphrodite, her capacities as a goddess of concord and harmony (Pirenne-Delforge, o.c. (n. 2), p. 406). Along the same lines, Parker argues that god-epithets such as Athena Hephaistia, or Aphrodite Peitho (that is, not a derivation of the name of a god or abstraction, but the lesser god or abstraction itself) designate "that part of Athena which resembles Hephaistos" and "the element of Peitho within Aphrodite", respectively (PARKer, l.c. (n. 1), p. 178, see also PARKER, l.c. (n. 19), p. 221, 225). These approaches are again not relevant when the epithet is "mortal" and not derived from the name of a deity. - For a discussion specifically of Zeus Aphrodisios, and an interpretation of the epithet Aphrodisios as designating "either the consort or male manifestation of the goddess, see S.L. BuDIN, "A reconsideration of the Aphrodite-Ashtart syncretism", Numen 51 (2004), p. 138.

36 BADIAN 1981, l.c. (n. 30), p. 41; BADIAN 1996, l.c. (n. 31), p. 13; M.P. NiLsson, Gescbicbte der griechischen Religion, vol. 2, München, 1950 (Handbuch der Altertumswiss., 5:2:2), p. 134.

37 A.D. Nock, "Notes on ruler-cult, I-IV", JHS 48 (1928), p. 41-42; L. ROBERT, Hellenica VI, Paris, 1948, 24-26; Cf. P. Fraser, "Zeus Selenkeios", CR 63 (1949), p. 92-94; J. \& L. Robert, "Bulletin Épigraphique”, REG 64 (1951), 133-134, no. 46.

38 V. DU SABLON, "Religiosité hellénistique et accès au cosmos divin", LEC 74 (2006), p. 4 et passim; Z. STEWART, "La religione" in R. Bianchi Bandinelli (ed.), Storia e cilviltà dei Greci 8, Milano, 1977, p. 532, 546, 557 et passim. Stewart stresses heavily that the search for salvation and protection largely concerns this life, not the afterlife. 


\section{A search for protection}

Today scholars tend to stress the continuity of Hellenistic religious customs with those of earlier centuries. ${ }^{39}$ Surely, what is visible as "change" in our sources is often the end result of gradual processes rather than sudden and sharp shifts in customs. However, their seeds certainly sown in preceding centuries, some changes are detectable and some concerns seem more pronounced. Increasing movement of people presented the polis with a more international outlook, and in a world where it was no longer self-evident that a citizen should be born, live and die in the same city, Hellenistic society stimulated religious interchange. In consequence, the Greeks both adopted foreign gods and created new ones through various forms of assimilation and/or syncretism. ${ }^{40}$ Furthermore, the Hellenistic world was a place dominated by new uncertainties. Entire cities could one day find themselves at the mercy of a single powerful individual, only to see these mighty rapidly fall from the height of power the next. The increasing popularity of the goddess Tyche is one well-known result of this fear of a fickle fate, and another is the abovementioned general preoccupation with security. ${ }^{41}$ Protection became a religious priority for states as well as individuals.

This concern for safety constitutes a nexus linking two other phenomena often considered symptomatic of the Hellenistic period: individual religious choices and the wish for a more intimate relationship with the gods. ${ }^{42}$ The flourishing of private cult associations is often presented as a typical consequence of this religious climate, ${ }^{43}$ because their popularity exemplifies that men and women to a larger extent chose to be initiated in mysteries and/or to participate in non-obligatory cults and religious associations, i.e., they were making more individual choices. ${ }^{44}$ But the associations actually illustrate the security preoccupation complex in its entirety. For a group of Hermaistai, gathering for celebrations of Hermes, ${ }^{45}$ the eponymous deity (as well as the

\footnotetext{
${ }^{39}$ See for example Du SABLON l.c. (n. 38), p. 19.

40 See for example Mikalson, l.c. (n. 26) \& MiKALSON, o.c. (n. 26), p. 208; BudiN l.c. (n. 35); PAKKANEN, Interpreting early bellenistic religion. A study based on the cult of Isis and the mystery cult of Demeter, Helsinki, 1996 (Papers and monographs of the Finnish institute at Athens, 3); A. MOTTE \& V. Pirenne Delforge, "Du « bon usage » de la notion de syncrétisme", Kernos 7 (1994), p. 1127.

${ }^{41}$ STEWART, l.c. (n. 38), 558-559.

42 Du SABLON l.c. (n. 38), p. 5.

43 STEWART, l.c. (n. 38), 512-514; 518.

44 STEWART, l.c. (n. 38), 513; PAKKANEN o.c. (n. 40), p. 113.

45 We do not know much about the ideas connecting the eponymous god to the members of his or her association. It has been suggested that a kind of birthday club hides behind associations named after a god: a group of Herakleistai or Dionysiastai would gather because they shared birthdays with these divinities (W. SCHMIDT, Geburtstag im Altertum, Gießen, 1908 [RGVV, 7], p. 12). In general however, scholars do not agree as to what extent club members were devotees
} 
community of the religious group) offered protection, and the voluntary choice of joining this particular association and god instead of another one was a sign of individual preferences. The personal religious choices simultaneously express the wish for closer connections to the gods. To place oneself under the protection of a certain god through membership in a club that was even more exclusive than the citizen body is clearly an aspiration to a more favoured relation to this god, as compared to non-members. We thus come full circle, as, in turn, the wish for a personal relationship to a divinity brings us back to the search for security, in that divine intimacy presumably was meant to lead to better protection and other advantages.

The collegial grouping of magistrates around a patron deity is another example of the Hellenistic axis wish for protection - individual cult choices - intimacy with the gods. ${ }^{46}$ Dedications presented by public officials, of both military and political status, provide testimony of a variant way of claiming special personal attention from a god, namely, through the use of very narrow epithets. ${ }^{47}$ For example, 17/16 BC, in Cyrene, a college of nomophylakes erected the statue of an Aphrodite called by the epithet Nomophylakis. Thus, as their protectress, they choose an Aphrodite exclusively connected to their team. The selected epithet personifies the professional task of the nomophylakes and provides an intimate link between worshippers and goddess..$^{48}$

of their divine eponym. The creation of a cult association might have strong social and economical aspects, rather than religious (STEWART, l.c. (n. 38), 513; V. GABRIELSEN, The naval aristocracy of Hellenistic Rhodes, Aarhus, 1997, p.123-124; PAKKANEN o.c. (n. 40), p. 113-114), and it has been suggested that membership (at least in an Athenian context) provided means for women, metics and slaves to access the polis via fellow full citizen members (M. LEIWO, "Religion, or other reasons? Private associations in Athens" in Early Hellenistic Athens. Symptoms of a change, Helsinki, 1997 (Papers and monographs of the Finnish Institute at Athens, 7), p. 111, 116.

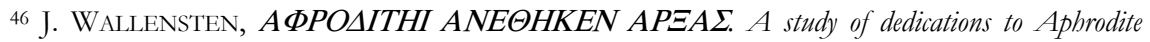
from Greek magistrates, diss. Lund University, Lund, 2003.

$47 \mathrm{It}$ is noteworthy that this procedure in a sense goes in the opposite direction of that of the religious clubs. Instead of gathering round a certain deity, thereby creating a cult association, magistrates, gathering because of a certain office, create a god. Whereas the Hermaistai take their name from the deity, single officials or groups of magistrates give their professional titles to the gods.

48 To the professional epithet Nomophylakis can be added other similar ones: strategoi honouring Aphrodite Stratagis, eisagogoi dedicating to Hermes Eisagogos and prytaneis to Zeus Prytaneus. SEG 9, 133; IG XII 6, 1; IG IX 12 256; SEG 62, 543bis. I would also add an inscription where a nauarchos of Pantikapeion made a dedication to Aphrodite Nauarchis, CIRB 30, to this group. Nanarchis is an epithet that obviously belongs to Aphrodite's aspect as a marine deity, she is an "admiral" in as much as she commands the sea. But I believe that in this particular case, the specific context of a dedication from a nauarchos to Nauarchis also allows an understanding of its meaning as a magistrates' epithet. The epithet simultaneously works on two levels: Nauarchis is the admiral's Aphrodite as well as the Admiral Aphrodite. Another result of this search for protection visible through epithets is the increasing attention given to deities (and humans) carrying the bynames Soter or Soteira. The epithet had connotations of salvation from most dangers, from disease and bad whether as well earthquakes and military threats (DU SABLON l.c. (n. 38), p. 7-9; A. Chaniotis, War in the Hellenistic world, Oxford, 2005, p. 146; MikaLson, o.c. (n. 26), passim). 
The devotion of Dikaios for Isis Aphrodite Dikaia is emblematic of the same security nexus and thus an almost expected product of the Hellenistic religious atmosphere. As illustrated by 'magisterial' epithets, one area in which individual religious choices and the wish for special protection coalesce consists of cults to gods defined by very narrow epithets. The creation of an epithet such as that of Dikaia is a further step in the direction showed by for example the closely defined magistrates' designations. Individual epithets, defined as formed from the name of specific persons, claim special relations and protection of a similar kind as that offered by the eponymity of the tutelary god of a cult association or by a professional epithet such as Nomophylakis, only of an even more restricted sort. ${ }^{49}$ Dikaios' and Asklepiades' relationship to the goddess is not acted out through the relative anonymity of membership in a group of worshippers, nor based on the rather impersonal status as holder of a certain public office. The search for deities directly and personally involved in the life of an individual, could not be expressed more clearly than a god bearing a family name. ${ }^{50}$ Through the designation Dikaia, this specific Isis Aphrodite provides personal protection as the made-to measure guardian exclusively of them and their close kin.

The presentation in an official sanctuary of an offering to a god bearing one's name is a bold public claim to a special relationship with the deity in question. An accompanying aspect of gratitude should however not be forgotten. The circumstances that first brought forth the honouring of Dikaia, and the reason the brothers believed they could claim divine goodwill, was perhaps a special favour granted Dikaios by Isis (and) Aphrodite, as in the case of Plutarch's account of Dexikreon. At a first glance - and perhaps with an anachronistic perspective - the act of naming a god after oneself looks presumptuous. But the relationship between gods and men was of course one of interchange. Inherent in the existence of Isis Aphrodite Dikaia are the humble servants Asklepiades and Dikaios Isidos Aphrodites. ${ }^{51}$

49 The process of "slimming down" epithets referring to the social group constituting the worshippers perhaps begins with bigger ethnic or kinship groups, i.e., in epithets such as Athena Phratria, Zeus Hellanios, etc. For this group, see for example PARKER, l.c. (n. 1) p. 178. I thank Dr. M. Mili for pointing this out.

50 STEWART, l.c. (n. 38), 555; Du SABLON l.c. (n. 38), p. 5.

51 It should also be noted that Isis and Aphrodite were powerful, but that their help, not the least in their Delian cults, could come at a prize, as in terms of "personal sacrifices", such as dietary requirements and restrictions in behaviour and appearance. STEWART, l.c. (n. 38), 543; Ph. BRunEAu, Recherches sur les cultes de Délos à l'époque bellénistique et à l'époque impériale, Paris, 1970, p. 465; 472-473; P. Roussel, o.c. (n. 8), p. 288; P. Roussel, Délos colonie athénienne, Paris, 1916, p. $269-270$. 


\section{The protection of Isis Aphrodite Dikaia}

Mikalson has suggested that the possibility of making choices as regards which god or goddess to honour made the selected deities more personal to their worshippers. ${ }^{52}$ Against this background, the combination of goddesses that was chosen as the personal protector of Dikaios and his family becomes interesting. ${ }^{53}$ Perhaps the pairing of Isis and Aphrodite provides a clue as to what kind of protection Isis Aphrodite Dikaia offered? As Parker points out, this type of pairing of deities does not necessarily imply an identification of the two. Thus, just as in the case of the Spartan goddess Aphrodite Hera, where Hera is not merely an epithet of Aphrodite, in our case Aphrodite is not a byname of Isis. ${ }^{54}$ The combination Isis and Aphrodite rather reinforces similar characteristics shared between them. In Delos, Isis' benevolence towards humans is clearly pronounced in the epigraphic sources, but both Isis and Aphrodite were goddesses considered close to man and so perhaps easily approached in personal matters. ${ }^{55}$ There were affinities between the (separate) Delian cults of Aphrodite Hagne and Isis, one being that dedications to these goddesses often were made after close encounters with them, erected after personal messages received in dreams or other visions. ${ }^{56}$ The Isis component of Dikaios' goddess furthermore had strong connotations of healing, health and protection of the family. ${ }^{57}$ Health and safety was also offered through participation in the worship of Aphrodite Hagne, whose cult became very

52 Mikalson, l.c. (n. 26), p. 211.

${ }^{53}$ It is of course not impossible that we should understand a kai between Isis and Aphrodite.

54 PARKer, l.c. (n. 19), p. 225.

55 DunAND, o.c. (n. 7), p. 113; Mikalson, o.c. (n. 26), p. 229. Du Sablon suggests that the traits of the Egyptian Isis that became most pronounced in the Greek cult of the goddess were those that were likely to lead to a more personal relationship to the divine sphere (DU SABLON l.c. (n. 38), p. 13).

56 See for example dedications by the order of a god, kata prostagma, sometimes through the assistance of an interpreter of dreams: IG XI 4, 1262, IDélos 2059, IDélos 2080 (Possibly to Isis Aphrodite), 2101, IDélos 2103, IDélos 2105, IDélos 2106, IDélos 2278, IDélos 2284, IDélos 2389, and especially IDélos 2098, made shortly after 158/157 BC, on the order of Sarapis, Isis Anoubis, Aphrodite, thus, Aphrodite together with the Egyptian gods. See also BrunEAU, o.c. (n. 51), p. 463-464; ROUSSEL, o.c., (n. 51), p. 270; H.S. VERSNEL, Inconsistencies in Greek and Roman religion I. Ter Unus. Isis, Dionysos, Hermes, Three studies in henotheism, Leiden, 1990, p. 40; HAuveTTEBesnault, l.c. (n. 23), p. 471-479. Aphrodite Hagne is of course the interpretatio graeca of the Syrian Goddess. The Syrian Goddess takes the name of Hagne Aphrodite at the time of our dedications. Because the assimilation was more or less complete at the time of IDélos 2158 - the Syrian goddess can for example be invoked by the name of Aphrodite only (IDélos 2265) and she is presented with erotes as an offering in IDélos 2251 and 2252) - I believe that this deity is of relevance for the discussion. See BrunEAU, o.c. (n. 51), p. 346, 470; RousSEL, o.c. (n. 51), p. 262.

${ }^{57}$ Mikalson, l.c. (n. 26), p. 213, 229; Du SABlon l.c. (n. 38), p. 13. 
popular during the period of Athenian domination. ${ }^{58}$ All these aspects of an Isis Aphrodite are also reinforced by the find context: the dedication was set up in Sarapieion C, where the Egyptian gods were approached as deities who listen to prayers, saviour gods, healers and maritime protectors. ${ }^{59}$ This last ability probably takes precedence in the context of an island trading centre: it is important that both goddesses were mighty protectresses of seafaring and mariners: in other cult contexts they both carry the epithet Euploia, for example. Did Dikaios need special attention because of frequent voyages or maritime trade interests? Or perhaps, as an Athenian in Delos in the late second/early first century BC, he simply travelled frequently between the island and its home city.

The literal meaning of the epithet, Just, or Righteous does not in itself provide information of the goddess' sphere of activities. To be sure, in a contemporary aretalogy from Maroneia, Isis is hailed, among a multitude of other praiseworthy qualities, as having instituted justice for men ${ }^{60}$ and furthermore the goddess Isis Dikaiosyne is present in an inscription from the Delian Sarapieion C. This is the same sanctuary where Dikaios and Asklepiades made their dedications and it is thus tempting to understand Dikaia as a conscious allusion to Dikaiosyne. But in the end, the goddess of IDélos 2158 was approached as Dikaia, and the epithet thereby merely gives us the character of Isis Aphrodite's behaviour. This might be precisely because the epithet Dikaia does not imply a specific aspect of the goddess as much as it draws attention to a special relationship between the dedicator and the goddess. Isis Aphrodite was 'Dikaian', 'of Dikaios'. ${ }^{61}$ Obviously, this interpretation does not - and should not - in any way exclude that the epithet simultaneously had connotations of justice. Just Isis Aphrodite would justly see to the best interests of her dedicated servants.

Jenny WALLENSTEN

Swedish Institute at Athens

Mitseon 9

GR-117 42 ATHENS

Greece

E-mail:jenny.wallensten@sia.gr

58 MikALSON, o.c. (n. 22), p. 235. For a recent study of aspects of the cult of Aphrodite in Delos, see C. DuRvYE, "Aphrodite à Délos: Culte privé et public à l'époque hellénistique”, REG 119 (2006) p. 83-113.

${ }^{59}$ BrunEau, o.c. (n. 51), p. 463-464; Roussel, o.c. (n. 8), p. 289-290.

${ }^{60}$ GrandjeAn, o.c. (n. 17), p. 18, 1. 24, 29. This act is not mentioned in other aretalogies. For Isis Dikaiosyne, see supra n. 17. Aphrodite on the contrary bears the epithet Unjust, Adikos, according to Hesychios.

${ }^{61}$ In fact, Dikaios or Dikaia, observant of rules, fitting, righteous, is a word mostly used for characters of men, not gods, and this perhaps also strengthens the interpretation of the goddess as the Dikaian Isis Aphrodite. 